\title{
SUBJETIVIDADE, INTERDISCIPLINARIDADE E DISCURSO DAS CIÊNCIAS HUMANAS NO PENSAMENTO DE JACQUES DERRIDA
}

\section{SUBJECTIVITY, INTERDISCIPLINARITY AND HUMANITIES DISCOURSE AT JACQUES DERRIDA THOUGHT}

\author{
Aline Magalhães Pinto \\ Doutora em História Social da Cultura pela Pontifícia Universidade Católica do Rio de Janeiro \\ Bolsista Fundação de Amparo à Pesquisa do Estado do Rio de Janeiro \\ E-mail: alinealinemp@gmail.com
}

\section{RESUMO}

A proposta deste texto é identificar a crítica de Derrida à subjetividade moderna para, em seguida, mapear o impacto dessa crítica e inflexão, apontando a tradução - no sentido que lhe é atribuído por Derrida - como possibilidade em aberto para a construção do discurso das ciências humanas.

Palavras-chave: Subjetividade. Interdisciplinaridade. Discurso. Tradução. Jacques Derrida.

\begin{abstract}
The purpose of this text is to identify Derrida's critique of modern subjectivity, and then map the impact of critical and inflection, pointing the translation - in the sense attributed to it by Derrida as an open possibility for the construction of the human sciences.
\end{abstract}

Keywords: Subjectivity. Interdisciplinarity. Speech. Translation. Jacques Derrida.

Numa fronteira, interdito e passagem se contaminam. Dobra de si pela qual o sujeito escreve, mas estraga-se na interrogação infinita sobre sua possibilidade. Nas faces contrapostas das páginas desta escrita porvir, desvia-se da busca por um passado com o qual controlar o futuro. O lugar de onde ela parte não é um espaço fechado, localidade de exclusão, um gueto. Não é o aqui empírico e nacional de um território. Escrever a partir de um lugar não é necessariamente tomá-lo como propriedade para encerrá-lo dentro de um discurso de representação a ser fixado e reificado. A escrita disseminada, itinerante, faz sulcos nos territórios por onde passa. Inventa um caminho inencontrável. Mas, ao mesmo tempo em que desenha, ela reconhece os gestos que produz. Como um registro nômade, a escrita e o pensamento de Jacques Derrida trabalham a historicidade dos 
textos como uma prática de interpretação que não reconstrói um sistema ou uma totalidade, mas encena o deslizamento e traslado dos sentidos de um texto a outro, reinscrevendo estes traços e os relançando novamente à interpretação e a inquietude.

A proposta deste texto é identificar a crítica de Derrida à subjetividade moderna para, em seguida, mapear o impacto dessa crítica e inflexão, apontando a tradução - no sentido que lhe é atribuído por Derrida - como possibilidade em aberto para a construção do discurso das ciências humanas.

Os acenos do pensamento de Jacques Derrida, no sentido de afiançar a indecibilidade entre jogo e "verdade", foram vistos ao longo dos anos 1980 e 1990, pelos setores mais tradicionais das ciências humanas, como uma retórica e irônica fuga da "realidade". Hoje, seu pensamento ainda enfrenta certa resistência, embora a situação seja bastante diferente, sobretudo pela repercussão, nas universidades americanas, do trabalho de importantes leitores de Derrida, como H. Bhabha e G. Spivak. Escapa às críticas mais ásperas feitas à filosofia de Derrida, o fato de que o jogo de interpretações não se refere em absoluto a um conjunto de movimentos arbitrários de um sujeito que, "conscientemente" ou abandonado à surrealístico inconsciente criativo, concebe imagens de realidade. Como mostra G. Vattimo, a defesa da "realidade" nestas críticas se faz à custa da condenação de tudo que parece aos olhos dos "realistas" pouco "real". Essa noção de "realidade" se constrói por meio de uma historicidade atrelada ao princípio de subjetividade moderno, encarnado num (improvável) sujeito universal, herói do conhecimento e da liberdade (VATTIMO, 2001, pp.18-21).

É por buscar romper com o universalismo do conceito de sujeito que o pensamento de Derrida é acusado não somente de "irreal", mas de irresponsável e antiético. Como afirma Duque-Estrada (2005, p. 253):

Liquidação, eliminação ou dissolução do sujeito é uma falsa imputação. A desconstrução do sujeito - mas isso vale também, como Derrida faz questão de deixar claro com frequência, para muitas outras formas de questionamento do sujeito que se desenvolveram notadamente na França por autores como Foucault, Deleuze, Lyotard e outros - significa antes um questionamento e um deslocamento de sua pretensa centralidade, de seu pretenso caráter originário ou fundamental. O sujeito passa a ser pensado a partir de múltiplas determinações, como ocupando um lugar numa certa economia, [...] numa rede mais ampla de conceitos.

A emancipação moderna tem seu núcleo normativo centrado no sujeito de uma história universal. A experiência desse tipo de sujeito é uma aposta na eternidade do presente, como medo de perder a identidade e o desejo de que o outro se torne Eu. Desestabilizá-lo seria ameaçar seriamente as ideias de homem, de humanidade, e os valores que as acompanham: liberdade, autonomia, igualdade... É exatamente a noção de "sujeito moderno" - centrado, unificado, 
autônomo, autossuficiente, dotado das capacidades de razão, consciência e ação - que se desconstrói diante do traço (DUQUE-ESTRADA, 2005, pp. 245-255).

Ante o traço, isso é, numa forma de pensar em que o tempo é textualizado e desponta a partir da disseminação do sentido, a escrita está sempre na iminência de deserdar o sujeito de seu espaço, porque lapida de espaçamentos o que outrora era tempo linear, lógico, da consciência, da representação verbal. Disso não resulta a "morte" do sujeito. O sujeito não um indivíduo inserido numa série de outros, nem a soma particular de diferentes séries dele mesmo. Mas, tão somente, "ele é" um sistema de relações entre as diferentes camadas textuais e psíquicas da sociedade, do mundo, e não a solidão soberana do escritor, leitor ou agente. Ao interpretar, escrever e ler: "ali eu estou, me encontro e me reencontro interessado, num texto que me transborda de todos os lados, mesmo onde não sei nada, onde não poderia reapropriar-me dele em consciência" (DERRIDA, 1996, p.4).

O sujeito foi descansar e em seu lugar há a máquina, aparelho que não funciona sozinho, mas em conjunto, em suplemento, suprindo sua finitude com o trabalho de se fazer e de se apagar. Toda inquietação histórica deságua numa máquina de escrita, sistema de gestos, coordenação de iniciativas independentes, multiplicidade de origens que deveria desequilibrar o espaço do corpo próprio. Escrever é ausentar-se, estar num limiar, ser passante e, ao mesmo tempo, construtor e desconstrutor das vias que atravessa. Os traços produzem seu espaço de inscrição na duração de seu desaparecer (DERRIDA, 1995, pp. 220-223). Como aponta Derrida (1995, p. 225):

\begin{abstract}
seguindo o caminhar das metáforas do caminho, do traço, da exploração, da marcha, sulcando uma via aberta por efração através do neurônio, a luz ou a cera, a madeira ou a resina para se inscrever violentamente numa natureza, numa matéria, numa matriz, seguindo a referência infatigável a uma ponta seca e a uma escrita sem tinta; seguindo a inventividade incansável e a renovação onírica dos modelos mecânicos, essa metonímia trabalhando indefinidamente a mesma metáfora, substituindo obstinadamente os traços pelos traços e as máquinas pelas máquinas.
\end{abstract}

Isso é, a cena da escrita desdobra-se, repete-se e denuncia a si própria. Nesse sentido, a relação entre a máquina e o sujeito torna-se fundamental para a compreensão da subjetividade para além dos limites traçados na experiência autocentrada do sujeito moderno.

O que Hegel, intérprete relevante de toda a história da filosofia, nunca pôde pensar, é uma máquina que funcionasse. Que funcionasse sem ser, nisto, regulada por uma ordem de apropriação. Tal funcionamento seria impensável enquanto inscreve a si mesmo em efeito de pura perda. Seria impensável como um não-pensamento que nenhum pensamento poderia superar, constituindo-o seu próprio oposto, como seu outro. A filosofia veria aí sem dúvida um não-funcionamento, um não-trabalho e faltaria por isso nela tudo o que, contudo em tal máquina funciona. Sozinha. Fora (DERRIDA, 1991, p. 146). 
O prefácio à Fenomenologia do Espírito mostra a passagem pela abstração matemática, pelo entendimento formal, pela exterioridade e morte como uma necessidade, como trabalho do negativo, ascese ou purificação do pensamento. Essa passagem é um desvio tão necessário e inescapável quanto é o retorno, a reconciliação, a reassunção do sentido. Nesse trajeto de regresso à consciência, da qual nada deveria se esquivar, Hegel percebe os registros gráficos não fonéticos e as operações do entendimento formal a partir do simbolismo matemático como resistências ao movimento de reassunção (aufhebung). "O silêncio desta escrita e o espaço deste cálculo [...] resistiram à interiorização do passado, à idealização relevante, à história do espírito, à reapropriação do logos na presença a si e a parusia infinita" (DERRIDA, 1991, p. 143).

Para Derrida, as críticas de Hegel às grafias não fonéticas, em especial aos ideogramas chineses, decorrem do fato de que essa escrita, ao não designar sons particulares, não se recolher a uma língua viva, paralisa-se longe do conceito, da consciência viva, no espaço da abstração formal, e adentra o jogo da disseminação de sentidos e acentos que não dizem respeito à representação das palavras faladas e presentes em si. Da mesma forma, os números também são estranhos ao conceito e consciência, da maneira como são entendidos dentro do pensamento hegeliano. A aritmética se abre à exterioridade. Os encadeamentos e diferenças numéricas que se apresentam como seu objeto, nela não residem, seu encadear não segue nenhuma necessidade. $\mathrm{O}$ número é a abstração da diversidade sensível e se o cálculo não se deixa interiorizar, resumir, superar no conceito, ele é pensamento puro e apartado da unidade da consciência. Ante essa cisão, o pensamento especulativo dissolve a distinção entre sujeito e objeto, entre passado e presente, entre sensível e inteligível, real e racional, levando-os ao plano do existir ou da presença: é o acesso ao fundamento da vida, ao qual infinitamente se retorna. Mas, para cumprir a tarefa de superação, retorno e reconciliação ao fundamento, o trabalho da formalidade, da matemática, do negativo, da exterioridade, da morte se faz necessário. É necessário que o espírito se exponha a seu outro e ali se perca, para que possa retornar (DERRIDA, 1991, pp. 145-146).

E, nesse momento em que o sentido se perde, em que o pensamento se opõe a seu outro, em que o espírito se ausenta de si mesmo, Derrida questiona: "é seguro o rendimento da operação?” A aposta derridiana é a de que a investigação e o questionamento que busquem escapar da necessidade de superação e reconciliação imposta pela dialética especulativa devam residir nesse ponto de insegurança, na negatividade abstrata, pensada sobretudo como diferença: intervalo único que separa o sentido de certo sem-sentido. Em Hegel esta diferença aparece administrada pelo pensamento especulativo, sendo tragada pelo movimento de superação-conservação, reassunção, aufhebung, da dialética. Hegel notou bem que a negatividade abstrata, diferença ou morte, se deixada a si, sem medidas, não poderia conduzir a outro lugar que não ao estranhamento e desconforto causado pela falta de sentido (DERRIDA, 1967, pp. 374-375). 
A negatividade abstrata seria um recurso utilizado pelo pensamento hegeliano para lidar com a instância de um gasto sem reserva, uma negatividade radical, traço em que a possibilidade de supressão, destruição, morte e sacrifício não têm limites. Ponto do qual não se possa retornar, em que o Espírito se perde e não sabe fazer o caminho de volta em seu trajeto. Ponto então em que o próprio trajeto se perde, e junto perde-se o sentido da história e da lógica. Chamar este "lugar" de negatividade abstrata e inseri-lo como necessário no movimento da dialética é uma forma de garantir que a historicidade e a experiência fiquem restritas aos limites da aufhebung, ou seja, àquilo que conserva e reproduz a presença e o presente. É ainda seguindo com Hegel até este ponto, seguindo o movimento até a negatividade, escancarando a face do negativo até que ela mostre o que seria sua positividade, que se pode, por um instante, vislumbrar que nunca houve, para o Espírito, um lugar para retornar, precisamente porque nunca houve um reverso, um positivo e um negativo, mas apenas e tão somente, o devir. Diante da "invenção" do negativo, levada a sério por Hegel (o que seria ao mesmo tempo motivo da grandeza e da desgraça do pensamento hegeliano), a decisão interpretativa teria sido a favor da necessidade da continuidade lógica do pensamento especulativo dialético. Essa decisão implica em tomar como negatividade o trabalho do Espírito, e reflete a posição hegeliana - e de toda a tradição ocidental que, de uma forma ou outra, retorna a Hegel - a favor da história universal, do sentido e da verdade, contra o jogo, o acaso e o riso (DERRIDA, 1967, pp. 376-377).

Mas, questiona Derrida (1991, p. 146):

o que seria um 'negativo' que não se deixasse superar? E quem seria, em suma; enquanto negativo, mas sem aparecer como tal, sem apresentar-se; isto é, sem trabalhar a serviço do sentido, teria sucesso? Mas teria sucesso, então, como pura perda?

Simplesmente uma máquina, talvez; e que funcionasse. Uma máquina definida no seu puro funcionamento e não na sua utilidade final, no seu rendimento, no seu trabalho.

Não se trata de atribuir uma essencialidade à técnica, mas de infligir ao texto e à escrita, a partir da metáfora tecnológica, a generalização de desencadeamentos múltiplos, mecanismo que trabalha no limite entre a finitude e infinitude, como registro sem fim de inúmeras interrupções. E, a partir daí, montar o texto e o discurso das ciências humanas como máquina. Ocupando o espaço de inscrição dupla de escrita-leitura, double bind, instante de fissura textual, desloca-se o trabalho historiador do lugar tradicional onde fazer história é representar, ou seja, reapresentar, trazer ao presente o que está escrito em outro texto. Posto este mecanismo, coloca-se em jogo e entram em cena lances textuais sem um passado presente, onde "vencedores", "vencidos", “colonizadores", “colonizados”, “metrópole”, “periferia”, “originais”, “cópias”, “puros”, “mestiços”... rompem a cumplicidade com a "origem", escapam violentamente da pertinência e à autoridade da "verdade", 
e dão corpo àquilo que, também por uma violência, não pôde existir como evento na história. Neste ângulo mudo e vazio da máquina, todos os termos estão de frente para sua morte, experimentam sua caducidade. Não se trata de representar, numa grande área chamada "humanidades", elementos "apropriados" de outrem com aparência de tradição escondida e status de origem, mas, de simular a apresentação de um texto que, antes de qualquer coisa, está ali, se dá à leitura e à reescrita, se escreve e se lê, apresenta-se e subtrai-se nessa operação incessante. $\mathrm{O}$ discurso das ciências humanas se situa, portanto, da perspectiva derridiana, nesse simulacro generalizado, entretextos de ficções, sejam as que se valem da pretensão de prevalência do "real", sejam as que já nasceram como ruína e derrota. Nos dentes dessa máquina textual, tudo se contamina e o resultado será outro, ainda não determinado (DERRIDA, 1991, pp. 326-328).

Ao liberar as vicissitudes da interpretação no ato de leitura-escrita disseminada, a máquina não tritura a possibilidade ética e democrática, mas inscreve esta possibilidade num terreno onde ela não será decidida pela verdade ou falsidade para um sujeito. Ao invés de regurgitar o já-ocorrido, passar em revista o passado para extrair uma verdade, os gestos interpretativos buscam encontrar, nos acontecimentos, desdobramentos por vir.

O desencadeamento do trabalho da máquina textual, mediante remarcações que se colocam insistentemente no texto, cessa o fenômeno de representação do ser-em-pessoa do sujeito, seja atuando como autor, agente, leitor, de maneira pré-estabelecida. O trabalho da máquina (uma máquina engenhosa, de teatro ou de guerra, uma máquina e uma maquinação, do mecânico e do estratégico) permite calcular a abertura ao não representável e, desta maneira, vai de encontro a outra noção de subjetividade (DERRIDA, 2004, pp. 35-38).

Como afirma S. Barnett, no pensamento de Derrida, a questão da subjetividade pode ser entendida como uma resposta à filosofia de Hegel, como crítica à metafísica da subjetividade. Para Hegel, a subjetividade deve agir a fim de se tornar o que é em si, como presença e permanência no mundo. O ser presente, que age, supõe o ser em relação como morte, como ausência ou seu negativo; e o supera. Para Derrida, a questão da subjetividade e da máquina não se põe como uma defesa triunfante da vida presente, nem elege a morte como horizonte de orientação. A máquina textual tem no sujeito uma função e engrenagem e está na corda bamba entre vida e morte. Sem ter o sujeito como base sólida e não ter um tempo presente como tutor, os discursos produzidos por essa máquina encontram-se na disjunção em que a referência é uma diferença aberta à alteridade (BARNETT, 1998, pp.131-145).

Essa diferença busca afastar-se do enclausuramento em torno da autoridade da presença e da verdade como presentificação, para lançar-se como abertura ao imprevisível e à inesperada vinda do outro. Esta abertura à alteridade enlaça o pensamento de Derrida ao de Levinas, de quem 
Derrida retém a concepção da atividade de pensar como um rigoroso e insólito ensino na figura do acolhimento e expõe o fato de que, ao descentrar o princípio de subjetividade moderno e inseri-lo no mecanismo da máquina textual, a ética acaba tendo prioridade sobre a ontologia. Não como substituta do pensamento do ser como presença, mas pela afirmação de que a ética não é uma subseção secundária da filosofia, que trata do modo como os seres humanos deveriam se relacionar uns com os outros e com o mundo que os rodeia. Seres humanos não preexistem às suas relações com o outro (DERRIDA, 2004, p. 23).

A noção de contaminação e de máquina não quer dizer que os homens se dissiparam das relações, mas que foram fundados por elas.

Como, onde aparece ou o que é a ética? Um dos paradoxos do que tento propor é que só há ética, só há responsabilidade moral, como se diz, ou decisão ética, ali onde não há mais regras ou normas éticas. Se há regras ou se há uma ética disponível, ou um conjunto de regras, nesse caso basta saber quais são as normas e proceder a sua aplicação, e assim não há mais decisão ética. O paradoxo é que, para haver decisão ética, é preciso que não haja ética, que não haja regras, nem normas prévias. É preciso reinventar cada situação singular ou regras que não existem previamente. Portanto, se tenho tanta dificuldade de utilizar essa palavra é, em particular, porque paradoxalmente sinto que a exigência de uma responsabilidade ética implica a ausência de uma ética, de um sistema ético e de uma norma ética (DERRIDA, 2001, s/p).

O outro ao qual se dirige a ética poderia ainda ser um homem? Sob quais circunstâncias se ainda haveria de insistir na clausura de certo "algo humano", fim em si mesmo, que reúne a todos em um "nós", nós "homens", nós "seres humanos"? Essa copertença e copropriedade se veem abaladas, mas não simplesmente pelo evento de emergência do texto disseminado e do jogo desconstrutor. Sua margem e finitude estavam marcadas na própria estrutura que lhe serve de base. O homem é o tema de uma história universal, que é escrita, entretanto, dentro de seus limites culturais, linguísticos, históricos, ou seja, nos limites da finitude humana. O fim do homem é prescrito e necessário no próprio pensamento da verdade do homem, porque homem é o que tem relação com seu fim (DERRIDA, 1991, p. 146, 161-163).

\footnotetext{
Nesse horizonte, não se está mais seguro do que quer dizer a palavra homem. Existe uma história do conceito de homem e é preciso se interrogar sobre essa história: de onde vem o conceito de homem, como o homem ele mesmo pensa o que é o próprio do homem? Por exemplo, quando tradicionalmente se opõe o homem ao animal, se afirma que o próprio do homem é a linguagem, a cultura, a história, a sociedade, a liberdade etc. Podem-se colocar questões sobre a validade de todas essas definições do "próprio" e do homem e, portanto, sobre a validade do conceito de homem tal como geralmente é utilizado. Colocar questões sobre esse conceito de homem é nada ter de seguro a esse respeito. Mas isso não quer dizer ser contra o homem. Frequentemente se acusa a desconstrução de, ao colocar questões sobre a história do conceito de homem, ser inumana, desumana, contra o humanismo. Nada tenho contra o humanismo, mas me reservo o direito de interrogar quanto à história, à genealogia e à figura do homem, quanto ao conceito do próprio do homem (DERRIDA, 2001, s/p).
} 
O desafio é pensar um fim do homem não organizado pela dialética da verdade e da negatividade, um fim que não se concretize como reapropriação na consciência daquilo que dela escapa, que não seja uma teleologia na primeira pessoa do plural. Um fim como recomeço, como rompimento e dessacralização da ordem que atrelou historicidade e ética aos ideais de subjetividade e liberdade. Outra historicidade espera outra ética e vice-versa. Uma "emancipação em devir”. Como afirma Nascimento (2006, pp. 65/66/70/71):

\begin{abstract}
o que dá origem à própria ética não é subsumível ao campo de uma orla estrita ou condicional. [...] Qualquer tentativa de um eu ou de uma cultura se propor dar este ou aquele sentido à alteridade radical, será sempre uma performance histórica, datada, limitada e, contudo, paradoxalmente indispensável [...] A decisão ética, a responsabilidade ética reinventada passa exatamente pela injunção de reavaliar cada situação singular em que a alteridade se apresenta enquanto tal. Aí onde não parece haver solução simples, aí onde as coisas se complicam em face do outro, é que é preciso tomar a decisão da melhor atitude, o gesto mais adequado e mais justo. E de maneira incondicional.
\end{abstract}

O nomadismo dessa concepção está atrelado ao "fato" de que a origem é différance, mas esta, sem lugar definido, desencadeia um processo de interminável diversificação. A unidade da origem se substitui pela proliferação atuante de sentidos. Desprovidos de um fundamento, os significantes se apagam. Restam diferenças. As reiteradas passagens pelas fronteiras da "ficção" e do "real" deixam marcas (sistemas, culturas, livros, documentos) sujeitas ao desgaste para dar lugar a outras marcas. Divisibilidade sem fim de remessas incontáveis. Naquilo em que uma leitura existencialista encontraria a figura de lugar, a perspectiva derridiana encena um gesto que põe em causa a própria figuração. Esse não lugar é uma zona de contatos e sobreposições que instigam hibridismos, exclusões, interdições e transgressões. Sem conformar um centro, um próprio ou uma identidade, essa estratégia se configura como um processo de tradução (SANTOS 2005, pp. 257-268).

O recurso à tradução como um processo cultural aparece no campo historiográfico na medida em que se estreitam as relações com a antropologia e a etnografia. O saber antropológico lida com a noção de tradução cultural desde suas primeiras configurações. Muitas vezes, a coleta de informações em campo depende do aprendizado de uma língua estrangeira, sendo pertinente examinar as próprias pressuposições linguísticas de missionários e etnógrafos nas suas descrições sobre outros povos (RINCÓN, 1999, pp.341-356).

Ao contrário de uma concepção restrita de tradução, o ato de traduzir não remete à atividade de transpor literalmente signos de uma língua para outra. Na dimensão desses encontros e traduções reside uma ambiguidade, pois encontrar e traduzir abre possibilidade para a confluência e troca, mas também para a colisão e cotejo. Da mesma forma que a tradução negocia 
e transporta as diferenças culturais, ela marca o corte, a distância entre elas. Ela pode funcionar, de acordo com Hartog, como um corte-sutura: nomeando o outro, classifica-o, domina-o (HARTOG, 1999, pp. 251-261).

Essas faces dos processos de tradução e encontro cultural não desaparecem nas entrelinhas para que venha à tona a formulação de um discurso que valorize híbridos e mestiços. Um encontro cultural pode apenas produzir outro silencioso e, na sequência, a imposição de um mutismo ou um monólogo. A tradução pode servir de sustento à "retórica da alteridade", se tende a transportar o outro ao idêntico numa interpretação definitória. Há uma promessa contida no horizonte da tradução de fazer cumprir a reconciliação da dispersão significante numa língua que é verdadeira por se referir somente a ela, autêntica e original. Ao privilegiar um significados entre tantos que um termo ou prática podem ter, a tradução pode anular o jogo das significações e apagar as demais significâncias do traduzido.

A necessidade da tradução está vinculada a uma luta pela apropriação do nome, do direito de nomear e estabelecer uma origem, um original. Nesse sentido, a tarefa da tradução é restituir o que era inicialmente dado, pagar uma dívida de sentido que o apropriado mantém com o próprio, o autêntico. A tradução, em seu deslocamento simbólico, deveria restituir, por contrato, a completude e a presença de sentido na identidade presumida a si de cada prática ou gesto cultural. O desdobramento do original na tradução marca uma aliança entre a origem e sua derivação. Essa aliança presume um acordo no qual a propriedade da composição cultural é direito do original, ao mesmo tempo em que concede ao tradutor a oportunidade de uma criação derivada (DERRIDA, 2002, pp.57-65).

Mas, se é fato que a tradução cultural pode apenas mascarar, numa diversidade de práticas e apropriações, a reiteração da gerência da hierarquia que sustenta a metafísica do sentido, se ela insinua uma vontade de compreender que visa antes transformar e transportar o diferente numa trajetória de pagamento e restituição ao próprio; ainda assim, contudo, ela não é capaz de evitar um gesto de mediação que provoca a abertura de um abismo na transição, na translação, na passagem à possibilidade de sentido. "A tradução é, simultaneamente, comunicação e obstáculo uma vez que as línguas [culturas] nunca se refletem umas nas outras como em um espelho" (SARLO, 2002, p. 50).

A tensão que se estabelece no processo de tradução entre aproximação/possibilidade e afastamento/conflito/impossibilidade é criativa, e leva a ter claro que o trabalho nunca está terminado ou perfeito. O conflito e incompletude são suas marcas indeléveis e fugir deles é também fugir da possibilidade de uma tradução cultural proveitosa. 
Nesse contexto trazemos à cena o ensaio Torres de Babel. No Gênesis (BIBLIA, A.T., 1990), narra-se a história da construção de uma cidade e de sua pretensa torre. Esse trecho bíblico conta que um povo, descendente de Noé, portanto, único sobre a Terra, após o grande dilúvio, e falante de uma única língua, quis construir uma cidade e, nessa cidade, uma torre que tocasse os céus. Tal feito tornaria esse povo glorioso e lhe permitiria continuidade sem dispersão, imperialismo, dominação e poder. Deus, não contente esse propósito, criou várias línguas para que os homens - até então falantes da mesma língua - não mais pudessem compreender uns aos outros. Por essa confusão entre as línguas, a torre não pôde ser terminada e a cidade recebeu o nome de Babel. Dessa forma, Deus faz valer sua vontade e transforma o destino desses homens, que se dispersam sobre a Terra, multiplicam-se e dão origem a novos povos. Babel é, pois, a grande metáfora da origem das diferentes línguas e, consequentemente, das diferentes culturas, uma vez que falar uma língua implica compartilhar uma cultura diferente daquela a qual pertence o outro. A tradução associa-se à ideia de Babel pelo fato de nascer, obrigatoriamente, no mesmo instante em que surge a pluralidade linguística superficial (DERRIDA, 2002, pp.12-18).

De inspiração benjaminiana, o comentário inscreve e intervém na atividade de tradução. Arrasta-a para o indecidível, delineando-a como um processo cultural no qual se dá o encontro instantâneo de tudo o que há, oriundo de todos os lugares e de todos os tempos - ao que sobrevém uma vaga impressão de desastre, de abismo - mas também como atividade que pressupõe um endividamento mútuo entre originais e traduções, na qual a ideia de fidelidade desaparece para trazer à tona uma responsabilidade (GLENADEL, 2005, pp.293-299).

A escrita derridiana faz ver que a necessidade da tradução encaminha à restituição do sentido. Entretanto, essa necessidade se dá como impossibilidade. Possibilidade-impossibilidade. A tradução trabalha nesse limiar: entre a impossibilidade da tradução total e completa, que leva a esbarrar no intraduzível, e as muitas possibilidades de diálogos, aproximações, tentativas e embates. Ela é como acontecimento semeador de significados. Nas passagens de um lugar a outro, de uma língua a outra, o intraduzível se revela como fruto da imposição e da interdição à tradução. Encarada como necessária e impossível, a tradução não é simplesmente a instância de defesa da propriedade do sentido, não reconcilia o sentido em sua propriedade e autenticidade. O desvio da tradução não pode pagar a dívida que contrai a não ser por remessa infinita a um território por definição intocável.

Este reino não é jamais atingido, tocado, pisado pela tradução. Existe o intocável e nesse sentido a reconciliação é apenas prometida. Mas uma promessa não é nada, ela não é marcada somente pelo que lhe falta para se realizar. Enquanto promessa já é um acontecimento e a assinatura decisiva de um contrato. Que ele seja ou não honrado não impede o engajamento de acontecer e de legar seu arquivo. Uma tradução que chega, que chega a prometer a reconciliação, a falar dela, a desejá-la ou fazer desejar, uma tal produção é um acontecimento raro e considerável (DERRIDA, 2002, p. 51). 
A completude simbólica não conhece seu final. A tradução se faz em atendimento à inevitabilidade: não há o retorno ao próprio. O nome próprio é exatamente o ponto em que isso se mostra na medida em que ele não se deixa facilmente traduzir, ele não é próprio de nenhum texto, de nenhum contexto. A resistência do nome próprio à tradução faz visível a não equivalência entre as "línguas", práticas e saberes que perpassam o mesmo ou diferentes textos. Em tradução, o nome próprio faz deslanchar um comentário, uma paráfrase, uma paródia, uma explicação, mas nunca uma equivalência.

Nomear violenta a suposta unicidade que se espera que se respeite, dá existência e a retira ao mesmo tempo. O nome próprio apaga o próprio que promete, quebra-se ou destrói, ele é a oportunidade da língua logo destruída: nomear denomina, o nome próprio despropria, desapropria, expropria no que chamamos eventualmente abismo do próprio ou do único (BENNINGTON; DERRIDA, 1996, p.81).

Diante do nome próprio, o tradutor esboça uma divisão que pensa e multiplica o sentido.

Ficar-se-ia tentado a dizer primeiramente que um nome próprio, no sentido próprio, não pertence propriamente à língua; ele não pertence a ela, ainda que, e porque seu apelo a torna (e) possível (que seria uma língua sem possibilidade de apelar ao nome próprio?); consequentemente ele não pode se inscrever propriamente na língua senão deixando-se nela traduzir, isto é, interpretar no seu equivalente semântico: desde esse momento ele não pode mais ser recebido como nome próprio (DERRIDA, 2002, p. 22).

A renúncia à tradução do nome próprio faz brilhar no texto aquilo cujo sentido não deixa transportar a outra linguagem sem dano. Ao fazê-lo, apenas faz figurar a multiplicidade irredutível das línguas. Essa renúncia exibe a incompletude, a impossibilidade do acabamento, da totalidade, da saturação de algo na ordem da edificação do sentido, da construção arquitetônica, do sistema e de sua arquitetura. Ela permite flagrar o ponto de emergência em que um texto - uma prática cultural - é cindido e perfurado naquilo que lhe é mais "próprio". Derrida dá corpo a essa fissura evocando a catacrese babélica:

[...] dando seu nome, Deus invocou a tradução, não apenas entre as línguas tornadas subitamente múltiplas e confusas, mas primeiramente de seu nome, do nome que ele clamou, deu e que deve traduzir-se por confusão para ser entendido, portanto para deixar entender que é difícil traduzi-lo e assim entendê-lo. No momento em que ele impõe e opõe sua lei àquela tribo, ele também é demandador da tradução. Ele também está endividado. Ele não parou de lastimar após a tradução do seu nome, ao passo que ele mesmo a interdita. Pois Babel é intraduzível. Deus lamenta sobre seu nome. Seu texto é o mais sagrado, o mais poético, o mais originário, posto que ele cria e se dá um nome, e não fica por isso menos indigente em sua força e própria riqueza, ele clama por um tradutor. [...] a lei não comanda sem ser lida, decifrada, traduzida (DERRIDA, 2002, pp. 40-41).

Dessa maneira, o afã ontoteológico de pagar a dívida, reenviar ao autêntico àquilo que se lhe deve, sofre um revés e um deslocamento. A demanda da tradução não reside mais em apenas um dos lados do contrato. Ao partir o texto em mais de uma língua, ao quebrar a pretendida pureza 
do original, a tradução não é mais uma dádiva que se concede como reapresentação àquele que precisa traduzir e que assim estaria para sempre endividado para com uma propriedade de sentido que lhe será sempre negada. Nos contornos da escrita derridiana, a estrutura do original é marcada pela exigência de ser traduzida, fazendo disso a lei: o original começa por endividar-se também em relação ao tradutor. O original é o primeiro devedor, o primeiro demandador, ele começa por faltar. Levando de uma margem a outra a propriedade de sentido, a inscrição derridiana permite a experiência da impossibilidade de decidir se um nome, um gesto, uma forma cultural, um corpo verbal pertencem propriamente, e simplesmente, a uma linguagem e a um território.

O sentido próprio não existe, sua "aparência" é uma função necessária — que se deve analisar como tal — no sistema das diferenças e metáforas. A parusia absoluta do sentido próprio, como presença a si no logos na sua voz, no ouvir-se-falar absoluto, deve ser situada como uma função respondendo a uma indestrutível, mas relativa, necessidade no interior de um sistema que a compreende (DERRIDA, 2004, p.113).

Nesse cenário, por tradução, se acessa um original já dobrado, rejuntado, que não pode ser apropriado, pois nunca foi propriamente ele mesmo. A questão seria: como traduzir um texto escrito em várias línguas ao mesmo tempo? Como 'devolver' o efeito de pluralidade? E se se traduz para diversas línguas ao mesmo tempo, chamar-se-á a isso de "traduzir"? A tradução, tal como perpetrada pela postura derridiana, faz-se como um "a traduzir". Processo paradoxal que lida com a letra, com o texto, não como vestimenta ou expressão transparente de uma verdade ou conteúdo, mas como uma inscrição e registro que se presta à tradução, mas que também resiste a ela. A tradução trabalha um corpo escrito, não como elemento físico não convencional, mas como elemento regulado pelas convenções ritualizadas nele inscritas, e performativizado pelo ato que lhe postula sentido em cada lance interpretativo. Um corpus textual não se deixa traduzir ou transportar. É aquilo que a tradução deixa de lado. Deixar de lado o corpo da escrita é a energia da tradução. Nesse corpus textual, para além do sentido, pretensamente transportado, há língua, gestos, vazios, que a tradução não traduz. A tradução então produz traços, restos do que é irrepresentável e não se deixou fixar. Um "macroprocesso" sem dúvida, uma expansão sem fronteiras que se põe a disseminar sentidos, mas sem se esquecer (ou esquecendo-se) que tudo se “iniciou” sem uma origem/naturalização de/um próprio (DERRIDA, 1995, p.198).

Como processo e movimento, traduzir não se reduz a apropriação total e infinita. Essa vacilação expõe que o sujeito não se apropria de uma língua, nem mesmo daquela que se chama "materna", mas deve suportar o corpo-a-corpo com ela. Mesmo quando só se tem a língua materna enraizada em seu lugar de nascimento, ela não pertence a um sujeito ou a uma cultura. O que lhe é mais próprio e específico é justamente o que não se deixa apropriar, que não é propriedade de 
ninguém. O que se manifesta, nas linhas quebradas de um texto que não pode ser ele mesmo e que, por isso, não pode ser uma propriedade. É um excesso como acontecimento da linguagem. Esse acontecer é a marca que liga a tradução à cultura. As práticas culturais e políticas do tradutor e do traduzido são transplantadas para o texto "original”. O acontecimento da tradução compreende-se como fenômeno de transplante e transferência de contextualizações histórico-temporais e de extratos culturais filtrados pelos hábitos literários e culturais impressos no ato tradutor, compondo transfigurações que - inevitável e irrecusavelmente - ficam embutidas num jogo que não tem fim. Nesse jogo, como aponta Derrida (2002, p. 69): "a tradução é a experiência, o que se traduz ou se experimenta também: a experiência é a tradução."

Essa experiência talha os processos histórico-culturais de maneira que, embora os deslocamentos sejam incessantes, eles não se dão numa aderência inconcussa, isentos e desembaraçados. A máquina textual se põe a traduzir como traço sobrevivendo ao presente do estilete, amarrado pela trama e pelo ardil, entre a fantasia e a ordem, entre a lei e a transgressão.

$\mathrm{Na}(\mathrm{s})$ escrita(s) disseminada(s), o trabalho do historiador tem tudo a ver com traduzir, saber textual, artístico e laborioso. Entender a historicidade como prática interpretativa que num procedimento ou máquina textual desloca e fixa elementos de um texto a/em outro, implica em conceder uma atenção especial à maneira como se dá esse transporte ou translado (ainda metáfora?) que cruza fronteiras, desorganizando-as, mas, ao mesmo tempo, confirmando novas margens. Essa escrita serve de base para a construção de um discurso das ciências humanas do qual se tem urgência num cenário em que a interpretação passa a ser uma condição de produção de sentidos e não mais um artifício usado para resgatar o sentido.

O discurso das ciências humanas, pensado pelo viés do pensamento de J. Derrida, vincula-se ao ato de traduzir pelo menos de duas formas.

Na medida em que movimenta tempos e espaços distintos, não mais contando com o suporte do tempo presente como organizador privilegiado, o trabalho das humanidades traduz esses tempos e espaços. Percebe-se essa escrita como morada do que está de passagem. Dimensão séria e cômica, em que a intervenção faz do jocoso uma forma de atuação que pode perpetrar o impensado, o incrível, o acaso na "verdade" daquilo que "existe", desestabilizando-a. A contaminação tira as máscaras e as devolve alhures, devidamente traduzidas, isto é, interpretadas e lançadas novamente ao jogo. O conhecimento produzido se torna a ousadia de romper com o "real", transitando entre o sublime e o vulgar. Um exemplo interessante é o trabalho de D. La Capra, historiador que faz dialogar Bakhtin e Derrida. A noção de 
carnavalização que ele mobiliza atua como iteração-alteração, combinando inversão, excentricidade, familiarização e profanação como formas de lidar com a aporia de uma historicidade que caminha entre a "ficção" e o "real", deixando marcas risonhas e também trágicas (LACAPRA, 1985, p.105-108).

Como foi sempre um procedimento textual que se alimenta de corpus conceituais e teóricos vindos de outros saberes e disciplinas, o pesquisador em ciências humanas traduz esses corpora "alienígenas" para o seu próprio. Nesse âmbito, a tradução se dá no trajeto em busca dos saberes precedentes e vizinhos, estabelecendo uma política de empréstimos teórico-metodológicos. Aqui, a tradução acaricia o coração das ciências, do homem, centro tão esmorecido das disciplinas, ao qual já custa lidar com ideia da utilização de "tropos" de linguagem para dramatizar o "fato". A tradução contribui para dissolver a perspectiva historiográfica - como produção de sentido unívoco - no entendimento de uma linguagem cultural como (trans)formação e intervenção (BENNINGTON; DERRIDA, 1996, pp.122-124).

Nos dois casos, estão envolvidas divisibilidade e impossibilidade. Entender o trabalho historiador como tradução implica lidar com a incompletude desse saber, assim como com a interpretação e criatividade envolvidas nessa atividade. A impossibilidade de se contar de uma vez por todas a história da cultura ocidental é o que torna envolvente e sedutor o horizonte de uma tarefa jamais cumprida. Interligadas, tradição e tradução cultural seriam, por assim dizer, “objetos" por excelência de história(s). Desfeita a pretensão de que o único destino de um evento passado seja encontrar seu sentido na relação que estabelece com aquilo que o seguiu - seu reconhecimento, sua presença evocada por aqueles que declararam ser seus seguidores, sua importância para o desfecho ou inauguração de um período - a continuidade está explodida, a tradição se entrega à tradução, que se doa a ela. São inseparáveis. Nessa cena, divisibilidade e incompletude, frente à performance do saber absoluto (Hegel), fazem desfilar uma rede "metafórica" a partir da noção de trans: transcrição, transcodificação, transformação, transculturalismo, transdisciplinaridade, transação, transferência, transatlântico... O movimento dessa rede pretende escapar às consequências da reassunção, desloca a marca das fronteiras hierárquicas e destitui o texto original como lugar da reconciliação e do sentido.

Nessa reviravolta em torno da dialética, se não há um texto original, consciente, autêntico, ao qual retornar, onde estarão guardados esses movimentos? Haveria ainda um lugar de consignação e de registro, ou a máquina textual dissemina, além do exorcismo do passado substancial, apenas dispersão? 


\section{REFERÊNCIAS}

BARNETT, S. Hegel after Derrida. New York, 1998.

BENNINGTON, G.; DERRIDA, Jacques. Jacques Derrida. Rio de Janeiro: Jorge Zahar, 1996.

DERRIDA, Jacques. Mal de arquivo: uma impressão freudiana. Rio de Janeiro: Relumé Dumará, 2001.

. L'écriture et la difference. Paris: 1967.

. Margens da filosofia, Campinas: Papirus, 1991.

. A escritura e a diferença. $2^{\mathrm{a}}$ ed. São Paulo: Perspectiva, 1995.

. O monolinguismo do outro. Porto: Campo das Letras Editores S.A. 1996.

. A solidariedade dos seres vivos. Entrevista por Evando Nascimento, publicada no suplemento Mais! Folha de São Paulo, em 27.5.2001. Disponível em: http://www.rubedo.psc.br/ Entrevis/solivivo.html)

. Gramatologia. $2^{\mathrm{a}}$ ed. São Paulo: Perspectiva, 2004.

. Torres de Babel. Belo Horizonte: Ed. UFMG, 2002.

. Adeus a Emmanuel Lévinas. São Paulo: Perspectiva, 2004.

DUQUE-ESTRADA, Paulo César. In: NASCIMENTO, Evando (Org.). Jacques Derrida: pensar a desconstrução. São Paulo: Liberdade, 2005.

GLENADEL, Paula. Desertos, senhas e miragens: a tradução e o pensamento derridiano. In: NASCIMENTO, E. (Org.). Jacques Derrida: pensar a desconstrução. São Paulo: Liberdade, 2005.

LACAPRA, Dominick. History \& criticism. Ithaca, 1985.

NASCIMENTO, Evando. Ética e política segundo Derrida. In: SANTOS, Alcides Cardoso dos. (Org.). Estados da Crítica. Cotia/Curitiba: Ateliê Editorial/Editora da Universidade Federal do Paraná, 2006.

RINCÓN, Carlos. "Antropofagía, reciclage, hibridación, traducción, o como apropiarse la apropiación." Nuevo Texto Crítico, nov.1999, p.341-356.

SANTOS, Alcides Cardoso dos. Desconstrução e visibilidade: a aporia da letra. In: NASCIMENTO, Evando (Org.). Jacques Derrida: pensar a desconstrução. São Paulo: Liberdade, 2005.

SARLO, Beatriz. A literatura na esfera pública. In: MARQUES, R.; VILELA, L.H. (Orgs.). Valores: arte, mercado, política. Belo Horizonte: Editora UFMG/Abralic, 2002.

SILVA, Francisco de Fátima. A indecidibilidade enquanto desconstrução da hermenêutica: a primazia da metáfora da escritura. Urutágua: Revista Acadêmica Multidisciplinar, $\mathrm{n}^{\circ}$ 6, Maringá, abr./jul.2005. Disponível em: http://www.urutagua.uem.br//006/06ffsilva.htm

VATTIMO, Gianni. A tentação do realismo. Rio de Janeiro: Instituto Italiano de Cultura; Nova Aguilar, 2001. (Conferências Italianas - 1) 